\title{
Mikhail Bakhtin
}





\section{Mikhail Bakhtin}

The Duvakin Interviews, 1973

EDITED BY SLAV N. GRATCHEV AND MARGARITA MARINOVA TRANSLATED BY MARGARITA MARINOVA

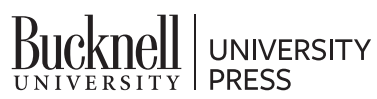

Lewisburg, Pennsylvania 
Library of Congress Cataloging-in-Publication Data

Names: Bakhtin, M. M. (Mikhail Mikhaulovich), 1895-1975, interviewee.|

Gratchev, Slav N., editor. | Marinova, Margarita (Margarita D.), editor, translator.

Title: Mikhail Bakhtin : the Duvakin interviews, 1973 / edited by Slav N.

Gratchev and Margarita Marinova ; translated by Margarita Marinova.

Description: Lewisburg, PA : Bucknell University Press, [2019] | Includes

bibliographical references and index.

Identifiers: LCCN 2018053290 | ISBN 9781684480913 (cloth) | ISBN 9781684480906 (paperback)

Subjects: LCSH: Bakhtin, M. M. (Mikhail Mikhaŭlovich), 1895-1975-Interviews.

Classification: LCC PG2947.B3 A5 2019 | DDC 801/.95092 [B]—dc23

LC record available at https://lccn.loc.gov/2018053290

A British Cataloging-in-Publication record for this book is available from the British Library.

This collection copyright $\odot 2019$ by Bucknell University Press

Individual chapters copyright $\left(C_{2019}\right.$ in the names of their authors

All rights reserved

No part of this book may be reproduced or utilized in any form or by any means, electronic or mechanical, or by any information storage and retrieval system, without written permission from the publisher. Please contact Bucknell University Press, Hildreth-Mirza Hall, Bucknell University, Lewisburg, PA 17837-2005. The only exception to this prohibition is "fair use" as defined by U.S. copyright law.

๑ The paper used in this publication meets the requirements of the American National Standard for Information Sciences-Permanence of Paper for Printed Library Materials, ANSI Z39.48-1992.

www.bucknell.edu/UniversityPress

Distributed worldwide by Rutgers University Press

Manufactured in the United States of America 